\title{
Evaluation of the Effect of Aortic Stenosis and Severity on Left Ventricular Function by Isovolumic Myocardial Acceleration
}

\author{
Aort Darlığ ve Ciddiyetinin Sol Ventrikül Fonksiyonuna Etkisinin İsovolumik Miyokardiyal \\ Akselerasyon ile Değerlendirilmesi
}

\author{
Ertan AKBAY \\ (D) 0000-0002-9146-0621 \\ Mehmet ERTÜRK \\ (D) 0000-0002-2468-2793 \\ Serkan YAZAN \\ (D) 0000-0003-4456-6818 \\ Mustafa Umut SOMUNCU \\ (D) 0000-0001-8786-1388 \\ Aydın YILDIRIM \\ (D) 0000-0002-0766-1544
}

\begin{abstract}
Aim: Tissue Doppler-derived isovolumic acceleration (IVA) is a parameter that evaluates the systolic function of both ventricles, without being affected by pre-load and post-load. We aimed to detect left ventricular systolic dysfunction at an early stage with IVA in patients with asymptomatic aortic stenosis (AS).

Material and Methods: A total of 105 patients were included in the study, 75 of which had isolated AS and 30 were free of any valve disease. Patients with AS were divided into three groups (mild, moderate and severe) according to their aortic valve area (AVA) and aortic peak velocities, as determined by means of a transthoracic echocardiography. Conventional echocardiography, systolic and diastolic Tissue Doppler parameters [peak myocardial velocity during isovolumic contraction (IVV), myocardial velocity during ejection phase (Sm), early diastolic myocardial velocity (e'), late diastolic myocardial velocity (a'), and acceleration time (AT)] were calculated in all patients. IVA was obtained by dividing the IVV flow rate by the AT time.

Results: The systolic parameters IVV $(\mathrm{p}<0.001), \mathrm{Sm}(\mathrm{p}<0.001)$, IVA $(\mathrm{p}=0.002)$ and diastolic parameters e' wave $(\mathrm{p}<0.001)$, a' wave $(\mathrm{p}=0.001)$ were found to be significantly lower in patients with AS compared to the control group. However, this relationship observed in IVA was not different in AS subgroups $(\mathrm{p}=0.122)$. Sm and $\mathrm{e}^{\prime}$ waves were positively correlated with AVA $(p=0.001, p<0.001$, respectively) and negatively correlated with aortic peak gradient ( $\mathrm{p}=0.008, \mathrm{p}<0.001$, respectively), but IVA was not correlated.

Conclusion: Left ventricular function is impaired in patients with AS and this is independent of the severity of AS.
\end{abstract}

Keywords: Aortic stenosis; isovolumic acceleration; tissue Doppler imaging.

\section{ÖZ}

Amaç: Doku Doppler kaynaklı isovolumik akselerasyon (IVA) her iki ventrikülün sistolik fonksiyonunu ön ve ard yükten etkilenmeden değerlendiren bir parametredir. Bu çalışmada asemptomatik aort darlığ (AD) olan hastalarda, sol ventrikül sistolik disfonksiyonun IVA ile erken aşamada tespiti amaçlanmıştır.

Gereç ve Yöntemler: Çalışmaya izole AD bulunan 75 hasta ve herhangi bir kapak hastalığı bulunmayan 30 hasta olmak üzere toplam 105 hasta dahil edildi. AD hastaları, transtorasik ekokardiyografi ile belirlenen aort kapak alanı (AKA) ve aortik pik velositeye göre üç gruba (hafif, orta ve ileri) ayrıldı. Konvansiyonel ekokardiyografi parametreleri, sistolik ve diyastolik doku Doppler parametreleri [isovolumik kontraksiyon esnasında oluşan pik miyokardiyal velosite (IVV), ejeksiyon fazında oluşan miyokardiyal velosite (Sm), erken diyastolik miyokardiyal velosite (e'), geç diyastolik miyokardiyal velosite (a'), akselarasyon zamanı (AT)] tüm hastalarda hesaplandı. IVA, IVV akım hızının AT süresine bölünmesiyle elde edildi.

Bulgular: Sistolik parametrelerden IVV $(p<0.001), \operatorname{Sm}(p<0.001)$, IVA $(p=0.002)$ ve diyastolik parametrelerden $\mathrm{e}^{\prime}$ dalgası $(\mathrm{p}<0.001)$, a' dalgası $(\mathrm{p}=0.001)$ AD bulunan hastalarda kontrol grubuna göre anlamlı şekilde düşük izlendi. Fakat IVA da izlenen bu ilişki AD alt gruplarında anlamlı değildi ( $\mathrm{p}=0.122)$. Sm ve e' dalgasının, AKA ile pozitif yönde (sırasıyla $\mathrm{p}=0.001, \mathrm{p}<0.001$ ) aortik pik gradiyentle negatif yönde korelasyonu vard1 (sırayla $\mathrm{p}=0.008$, $\mathrm{p}<0.001$ ), ancak IVA ise korele değildi.

Sonuç: AD olan kişilerde sol ventrikül fonksiyonu bozulmuştur ve bu AD ciddiyetinden bağımsızdır.

Anahtar kelimeler: Aort darlığı; isovolumik akselerasyon; doku Doppler görüntüleme.
Received / Geliş Tarihi : 04.05.2020

Accepted / Kabul Tarihi : 20.09.2020 Available Online /

Çevrimiçi Yayın Tarihi : 25.12.2020

$\overline{\text { Presented as a poster at } 30^{\text {th }} \text { National Cardiology Congress, (October 23-26, 2014, Antalya, Turkey) }}$ 


\section{INTRODUCTION}

Aortic stenosis (AS) is the most common acquired heart valve disease in the population $(2-7 \%)$ over 65 years (1). With the onset of symptoms, it shows a very rapid progression (2,3). 50-60\% of patients who are not treated surgically are lost in approximately 2 years $(4,5)$. Decreased left ventricular (LV) ejection fraction (EF) and the development of symptoms in AS are associated with poor prognosis (6). In addition, the presence of subclinical systolic dysfunction has been associated with mortality in patients with asymptomatic severe AS with preserved EF (7).

Recently, tissue Doppler imaging (TDI) and/or strain/strain-rate imaging have proven to be effective in demonstrating both global and regional LV systolic functions. Although LV EF is preserved in patients with AS, subclinical systolic dysfunction in the left ventricle has been demonstrated by both the S' wave obtained by TDI and the strain measured using two and three-dimensional speckletracking (8-16). It is known that TDI measurements are angle-dependent, influenced by the pre-load and after-load, and strain/strain-rate imaging requires complex programs, requires good image quality and is time consuming. Isovolumic acceleration (IVA), which is calculated by tissue Doppler method, is an easily measurable parameter in showing right ventricular (RV) and LV systolic functions. It is unaffected by pre-load and after-load (17-20). Experimental and clinical studies with IVA have shown strong correlation with invasive and non-invasive measurements of LV function (18-21). Although it is so advantageous, it is not used enough in our daily practice.

Its easy application will allow early intervention before myocardial damage becomes apparent or symptoms begin. There are no previous data comparing the severity of AS with healthy people. In this study, we aimed to evaluate the effect of asymptomatic AS on LV systolic function using TDI-derived IVA.

\section{MATERIAL AND METHODS}

A total of 105 patients; 75 patients with isolated AS (36 male, 39 female, mean age $65.7 \pm 11.5)$ and 30 patients without any valve disease (15 male, 15 female, mean age $63.9 \pm 6.0$ ) were included in the study. All were evaluated by transthoracic echocardiography (TTE) and TDI. Those with AS were divided into three groups (mild, moderate and severe) according to their aortic valve area (AVA) and aortic peak velocities (APV) determined by TTE. Mild AS (AVA $>1.5 \mathrm{~cm}^{2}, \mathrm{APV}<3 \mathrm{~m} / \mathrm{sec}$ ) was found in 24 patients, moderate AS (AVA=1-1.5 $\left.\mathrm{cm}^{2}, \mathrm{APV}=3-4 \mathrm{~m} / \mathrm{sec}\right)$ in 20 patient and severe AS $\left(\mathrm{AVA} \leq 1.0 \mathrm{~cm}^{2}, \mathrm{APV} \geq 4 \mathrm{~m} / \mathrm{sec}\right)$ was found in 31 patients (22).

In addition, patients with mildly more severe valve disease other than AS, low ejection fraction $(\mathrm{EF}<50)$, congenital heart disease, subvalvular and supravalvular AS, left bundle branch block, atrial fibrillation, pacemaker rhythm, chronic renal failure, ischemic ECG changes, and those with angina and/or acute coronary syndrome were all excluded from the study. Approval was sought and obtained by the ethics committee of the Istanbul Mehmet Akif Ersoy Thoracic and Cardiovascular Surgery Training and Research Hospital on December 16, 2013, decision number 16 . Written informed consent was obtained from all patients prior to enrollment and the study was performed in the Helsinki Declaration.

\section{Conventional Echocardiography}

A GE-Vivid 6 instrument (Horten, Norway) 2-4 MHz transducer was used to perform the echocardiographic evaluation of the patients and all images were recorded on digital media. Patients were evaluated with the parasternal long axis, apical four cavities, two cavities and five cavities images according to the guidelines. Two-dimensional, Mmode, PW, CW-Doppler and color flow Doppler echocardiographic measurements were performed. All images were recorded in a single-lead ECG recording and were calculated by averaging 5 consecutive cycles.

In the parasternal long axis window, LV end diastolic (LVEDD) and LV end systolic diameters (LVESD), LV outflow tract (LVOT) diameter, left atrial (LA) diameter, LV septum thickness (IVS) and posterior wall thickness (PW) were measured. Left ventricular mass (LVM) was calculated using the Devereux equation (23):

\section{$\mathrm{LVM}=0.8\left\{1.04\left[\left([\mathrm{LVEDD}+\mathrm{IVST}+\mathrm{PWT}]^{3}-\mathrm{LVEDD}^{3}\right)\right]\right\}+0.6$}

The left ventricular mass index (LVMI) was calculated by dividing the LVM by the body surface area. LVOT cross sectional area (CSA) was calculated by taking the LVOT diameter. LV end-diastolic volume (LVEDV) and LV endsystolic volume (LVESV) were measured from the apical four-chamber and two-chamber images and the LV EF was calculated using the modified Simpson method (24). The CW-Doppler was placed on the aortic valve from the apical 5-chamber image and the aortic time velocity integral (TVI), maximal and mean aortic gradients were measured. LVOT TVI was measured by the PW-Doppler over the LVOT. AVA was calculated using the continuity equation $(6,22)$ :

LVOT CSA $\left(\mathrm{cm}^{2}\right)=0.785 \times(\text { LVOT Diameter })^{2}$

\section{AVA $=($ LVOT CSA $x$ LVOT TVI $) /$ Aortic TVI}

In addition, the PW-Doppler was used to measure the early (E) and late (A) diastolic flow velocities and deceleration time (DT).

\section{Tissue Doppler Imaging (TDI)}

TDI measurements were performed at a high frame rate (>150 fps), using minimal optimal gain, with transducer frequency between 3.5 and $4.0 \mathrm{MHz}$, with the Nyquist limit set to $15-20 \mathrm{~cm} / \mathrm{sec}$. The monitor sweep rate was set to 50 to $100 \mathrm{~mm} / \mathrm{sec}$ in order to optimize the spectral analysis of the myocardial velocities. Apical window images were selected to quantify regional wall motions simultaneously with Doppler inflow and outflow currents and to minimize the angle between Doppler beam and wall motion. A $5 \mathrm{~mm}$ pulsed Doppler sample volume was placed in the basal portion of the LV medial and lateral wall, at the end of the expiration on apical 4-chamber images (25). Peak myocardial velocity during isovolumic contraction (IVV), myocardial velocity during ejection phase $(\mathrm{Sm})$, early diastolic myocardial velocity (e'), late diastolic myocardial velocity (a') flow rates and acceleration time (AT), were calculated by TDI. All measurements were calculated by averaging 5 consecutive cycles. IVA was obtained by dividing the IVV flow rate by the AT time (Figure 1):

$\mathrm{IVA}=\mathrm{IVV} / \mathrm{AT}$

Global LV tissue Doppler measurements were obtained by averaging the tissue Doppler parameters measured from the septal and lateral walls. 


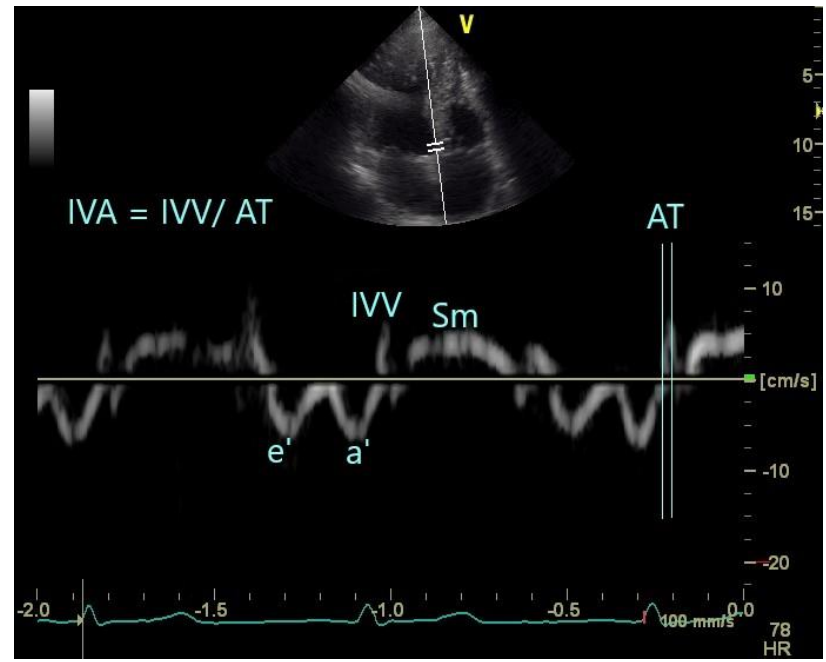

Figure 1. Tissue Doppler imaging-derived IVV and AT obtained from left ventricular septal basal wall of patients with aortic stenosis. IVV; peak myocardial velocity during isovolumic contraction; AT; isovolumic acceleration time, $\mathrm{Sm}$; myocardial velocity during ejection phase, e'; early diastolic myocardial velocity, a'; late diastolic myocardial velocity, IVA; isovolumic acceleration

\section{Statistics Analysis}

In all statistical analysis, we used the SPSS v.21.0 statistical package. Distribution of the variables were tested with the Kolmogorov-Smirnov normality test. Descriptive statistics were expressed as mean \pm standard deviation (SD) or median, interquartile range (IQR) and minimum-maximum values depending on the distribution pattern. Categorical variables were expressed as frequency and percentages. If there was a normal distribution, the independent samples $t$ test was used to compare two groups, one-way ANOVA was used when comparing more than two groups; if there was no normal distribution, the Mann-Whitney U test was used to compare two groups, the Kruskal-Wallis test was used to compare more than two groups. Tukey and Mann-Whitney U test with Bonferroni correction were used to determine which group caused the difference. The correlation analysis was performed using the Spearman correlation analysis and categorical variables were analyzed with Pearson chi-square test. The cases where the $p$ value was less than 0.05 were evaluated as statistically significant.

\section{RESULTS}

\section{Clinical Properties}

There was no statistically significant difference in traditional risk factors and drug use between AS patients and the control group (Table 1). There was no statistically significant difference in these parameters between the subgroups of patients with AS (Table 1).

Two Dimensional and CW-Doppler Echocardiography Parameters

LVEDD, LVVESD, LV EF, LVEDV and LVESV parameters did not differ between the AS and the control group (Table 2). Similarly, no difference was found in these parameters between the AS subgroups (Table 2).

IVS, PW, LVMI and LA diameter were found to be significantly higher in the AS group compared to the control group (Table 2). LVMI and IVS thickness were found to be significantly lower in mild AS compared

Table 1. Demographic characteristics of the patients with aortic stenosis and control group

\begin{tabular}{|c|c|c|c|c|c|c|c|}
\hline & \multirow{2}{*}{ AS Total $(n=75)$} & \multirow{2}{*}{ Control $(\mathbf{n}=\mathbf{3 0})$} & \multirow{2}{*}{$\mathbf{p}$} & \multicolumn{4}{|c|}{ Severity of AS } \\
\hline & & & & Mild (n=24) & Moderate (n=20) & Severe $(n=31)$ & $\mathbf{p}$ \\
\hline Age (year) & $65.7 \pm 11.5$ & $63.9 \pm 6.0$ & 0.408 & $61.6 \pm 11.6$ & $68.0 \pm 10.7$ & $67.6 \pm 11.4$ & 0.098 \\
\hline \multicolumn{8}{|l|}{ Gender, n (\%) } \\
\hline Male & $36(48.0)$ & $15(50.0)$ & \multirow{2}{*}{0.853} & $11(45.8)$ & $9(45.0)$ & $16(51.6)$ & \multirow[t]{2}{*}{0.870} \\
\hline Female & $39(52.0)$ & $15(50.0)$ & & $13(54.2)$ & $11(55.0)$ & $15(48.4)$ & \\
\hline Body mass index $\left(\mathrm{kg} / \mathrm{m}^{2}\right)$ & $28.4 \pm 4.9$ & $28.5 \pm 3.9$ & 0.575 & $28.8 \pm 4.3$ & $28.6 \pm 6.3$ & $27.8 \pm 6.3$ & 0.683 \\
\hline Body surface area $\left(\mathrm{m}^{2}\right)$ & $1.9 \pm 0.2$ & $2.0 \pm 0.2$ & 0.086 & $1.9 \pm 0.2$ & $1.9 \pm 0.2$ & $1.8 \pm 0.2$ & 0.412 \\
\hline Heart rate (beats/min) & $76.4 \pm 14.0$ & $79.7 \pm 11.7$ & 0.242 & $75.6 \pm 13.4$ & $78.7 \pm 15.5$ & $75.5 \pm 13.7$ & 0.700 \\
\hline Systolic BP (mm Hg) & 138 (29) [103-207] & $130(20)$ [110-159] & 0.192 & $140(45)$ [105-200] & 140 (33) [103-183] & $131(22)$ [110-207] & 0.332 \\
\hline Diastolic BP (mm Hg) & 79 (20) [42-130] & $70(10)[60-90]$ & 0.507 & $80(16)[57-130]$ & $79(20)[57-110]$ & $70(23)[42-101]$ & 0.032 \\
\hline Hypertension, n (\%) & $54(72.0)$ & $16(53.3)$ & 0.067 & $17(70.8)$ & $15(75.0)$ & $22(71.0)$ & 0.941 \\
\hline Diabetes mellitus, n (\%) & $23(30.7)$ & $8(26.7)$ & 0.685 & $7(29.2)$ & $7(35.0)$ & $9(29.0)$ & 0.886 \\
\hline Current smoking, n (\%) & $29(38.7)$ & $9(30.0)$ & 0.404 & $2(8.3)$ & $6(30.0)$ & $7(22.6)$ & 0.181 \\
\hline $\mathrm{CAD}, \mathrm{n}(\%)$ & $15(20.0)$ & $3(10.0)$ & 0.219 & $7(29.2)$ & $9(45.0)$ & $13(41.9)$ & 0.499 \\
\hline Hyperlipidemia, n (\%) & $25(33.3)$ & $10(33.3)$ & 1.000 & $8(33.3)$ & $4(20.0)$ & $13(41.9)$ & 0.268 \\
\hline \multicolumn{8}{|l|}{ Drug use, n (\%) } \\
\hline ACE inhibitor & $25(33.3)$ & $12(40.0)$ & 0.518 & $9(37.5)$ & $10(50.0)$ & $6(19.4)$ & 0.067 \\
\hline ARB & $16(21.3)$ & $3(10.0)$ & 0.173 & $6(25.0)$ & $2(10.0)$ & $8(25.8)$ & 0.351 \\
\hline Statin & $26(34.7)$ & $6(20.0)$ & 0.140 & $9(37.5)$ & $4(20.0)$ & $13(41.9)$ & 0.258 \\
\hline Beta blocker & $30(40.0)$ & $7(23.3)$ & 0.106 & $8(33.3)$ & $7(35.0)$ & $15(48.4)$ & 0.458 \\
\hline $\mathrm{CCB}$ & $16(21.3)$ & $5(16.7)$ & 0.589 & $2(8.3)$ & $5(25.0)$ & $9(29.0)$ & 0.159 \\
\hline
\end{tabular}

blocker, descriptive statistics were given as meantstandard deviation for normally distributed variables, otherwise median (interquartile range) [minimum-maximum] were used 
to severe AS ( $p<0.001, p=0.002$, respectively), but there was no statistically significant difference between the other subgroups $(p>0.017)$. PW thickness was significantly lower in mild and moderate AS subgroups than in the severe AS subgroup ( $p<0.001, p=0.004$, respectively), but there was no statistically significant difference between the mild and moderate AS subgroups $(p=0.230)$. LA diameters increased with the degree of AS, but this increase was not statistically significant $(\mathrm{p}=0.058)$. PW-Doppler and Tissue Doppler Echocardiography Parameters

E wave, A wave, DT, E/e' ratio, e' wave, a' wave, IVV, Sm parameters were found to be statistically significantly different when the AS and the control groups were compared (Table 3). When subgroups of AS were compared to each other, E wave, A wave, DT, E/A ratio, and a' wave parameters were not observed to be different between the groups (Table 3).

E/e', e', IVV and Sm were found to be statistically different among subgroups of AS ( $\mathrm{p}=0.005, \mathrm{p}<0.001, \mathrm{p}=0.016$, $\mathrm{p}=0.029$, respectively). When the groups were compared with each other, the E/e' and Sm were significantly different in the mild and severe AS subgroups, the e' wave in the mild to moderate AS and mild to severe AS, the IVV parameter was statistically different between the mild and moderate AS subgroups ( $\mathrm{p}=0.001, \mathrm{p}=0.011, \mathrm{p}=0.016$, $\mathrm{p}<0.001, \mathrm{p}=0.003$, respectively). There was no significant difference in other subgroup comparisons ( $p>0.017$ ).

IVA was significantly lower in the AS group than in the control group $(p=0.002)$. However, in the subgroup analysis, IVA was did not differ in severity of the stenosis $(\mathrm{p}=0.122)$.

Table 2. Comparison of two-dimensional, M-mode and CW-Doppler echocardiographic parameters of aortic stenosis patients and control group

\begin{tabular}{|c|c|c|c|c|c|c|c|}
\hline & \multirow{2}{*}{ AS Total $(n=75)$} & \multirow{2}{*}{ Control (n=30) } & \multirow{2}{*}{$\mathbf{p}$} & \multicolumn{4}{|c|}{ Severity of AS } \\
\hline & & & & Mild (n=24) & Moderate $(n=20)$ & Severe $(n=31)$ & $\mathbf{p}$ \\
\hline $\operatorname{LVEDD}(\mathrm{mm})$ & $48.4 \pm 4.5$ & $47.8 \pm 3.5$ & 0.532 & $48.3 \pm 4.8$ & $50.0 \pm 4.6$ & $40.7 \pm 4.0$ & 0.183 \\
\hline LVESD (mm) & $30.3 \pm 4.5$ & $29.8 \pm 2.7$ & 0.527 & $30.2 \pm 4.9$ & $31.7 \pm 4.7$ & $29.4 \pm 3.9$ & 0.213 \\
\hline IVS (mm) & $12.0(3.0)[0.9-2.1]$ & $10.0(1.0)[0.9-1.3]$ & $<0.001$ & $11.5(1.0)[0.9-1.5]$ & $12.0(3.0)[1.0-1.6]$ & $13.5(3.0)[1.2-2.1]^{*}$ & $<0.001$ \\
\hline $\mathrm{PW}(\mathrm{mm})$ & $12.0(2.0)[0.9-1.7]$ & $10.0(0.5)[0.9-1.2]$ & $<0.001$ & 11.0 (1.8) [0.9-1.3] & $11.0(2.0)[1.0-1.4]$ & $12.0(2.7)[1.1-1.7]^{\#}$ & $<0.001$ \\
\hline $\operatorname{LVEF}(\%)$ & $61.0(5.0)[50-70]$ & $60.0(3.7)[55-70]$ & 0.980 & $62.0(4.0)$ [52-69] & $62.0(7.0)[55-70]$ & $60.5(5.0)[50-70]$ & 0.830 \\
\hline LV diastolic volume (ml) & $112.1 \pm 24.6$ & $104.9 \pm 24.2$ & 0.179 & $109.8 \pm 26.5$ & $112.1 \pm 22.6$ & $114.0 \pm 25.1$ & 0.822 \\
\hline LV systolic volume (ml) & $40.0(19.0)$ [23-85] & 40.5 & 0.511 & 37.5 (26.0) [23-68] & 40.0 (13.0) [27-80] & $43.0(23.2)$ [25-85] & 0.904 \\
\hline $\operatorname{LVMI}\left(\mathrm{gr} / \mathrm{m}^{2}\right)$ & $123.4 \pm 33.7$ & $91.8 \pm 17.6$ & $<0.001$ & $106.4 \pm 20.5$ & $121.4 \pm 29.6$ & $137.5 \pm 38.7^{\&}$ & 0.008 \\
\hline \multirow[t]{6}{*}{ LA diameter (cm) } & $3.9(0.6)$ [2.8-5.0] & $3.6(0.3)[3.2-4.2]$ & 0.003 & $3.8(0.4)[2.8-4.5]$ & $3.9(0.9)[3.0-5.0]$ & $4.0(0.5)[3.4-4.9]$ & 0.058 \\
\hline & \multicolumn{3}{|c|}{ Aortic valve area $\left(\mathrm{cm}^{2}\right)$} & $1.7 \pm 0.1$ & $1.3 \pm 0.2$ & $0.8 \pm 0.2$ & $<0.001^{\wedge}$ \\
\hline & \multicolumn{3}{|c|}{ Aortic peak velocity (m/sn) } & $2.7 \pm 0.1$ & $3.5 \pm 0.3$ & $4.6 \pm 0.5$ & $<0.001^{\wedge}$ \\
\hline & \multicolumn{3}{|c|}{ Aortic peak gradient (mm Hg) } & & & & \\
\hline & \multicolumn{3}{|c|}{ Maximum } & $29.3 \pm 2.4$ & $50.1 \pm 7.7$ & $87.4 \pm 19.1$ & $<0.001^{\wedge}$ \\
\hline & \multicolumn{3}{|c|}{ Mean } & $16.1 \pm 1.7$ & $30.4 \pm 10.8$ & $52.8 \pm 12.6$ & $<0.001^{\wedge}$ \\
\hline
\end{tabular}

AS: aortic stenosis, LVEDD: left ventricular end-diastolic diameter, LVESD: left ventricular end-systolic diameter, IVS: left ventricular septum thickness, PW: posterior wall thickness, LVEF: left ventricular ejection fraction, LV: left ventricle, LVMI: left ventricular mass index, LA: left atrium; *: p=0.002 vs mild, \#: p<0.001 vs mild and $\mathrm{p}=0.004$ vs moderate, ${ }^{\&}: \mathrm{p}<0.001$ vs mild, $\wedge$ : $\mathrm{p}<0.001$ between all subgroups, descriptive statistics were given as mean \pm standard deviation for normally distributed variables, otherwise median (interquartile range) [minimum-maximum] were used

Table 3. Comparison of PW and tissue Doppler echocardiographic parameters of aortic stenosis patients and control group

\begin{tabular}{|c|c|c|c|c|c|c|c|}
\hline & \multirow{2}{*}{ AS Total $(n=75)$} & \multirow{2}{*}{ Control (n=30) } & \multirow{2}{*}{$\mathbf{p}$} & \multicolumn{4}{|c|}{ Severity of AS } \\
\hline & & & & Mild (n=24) & Moderate (n=20) & Severe $(n=31)$ & $\mathbf{p}$ \\
\hline E wave $(\mathrm{cm} / \mathrm{sn})$ & $80.0(40.0)$ [40-150] & 78.5 (23.0) [33-100] & 0.013 & $78.0(29.0)[46-135]$ & $84.0(40.0)[50-120]$ & ] $77.5(33.0)[40-150]$ & 0.711 \\
\hline A wave (cm/sn) & $102.2 \pm 29.1$ & $78.8 \pm 17.5$ & $<0.001$ & $95.2 \pm 27.6$ & $107.5 \pm 25.0$ & $104.3 \pm 32.3$ & 0.334 \\
\hline $\mathrm{E} / \mathrm{A}$ rate & $0.78(0.5)[0.4-2.1]$ & $0.96(0.4)[0.4-1.7]$ & 0.147 & $0.78(0.5)[0.5-1.5]$ & $0.75(0.5)[0.5-1.3]$ & $0.79(0.4)[0.4-1.5]$ & 0.580 \\
\hline DT (msn) & $306.2 \pm 73.5$ & $255.5 \pm 60.7$ & 0.001 & $279.9 \pm 51.1$ & $324.3 \pm 88.4$ & $314.9 \pm 74.3$ & 0.094 \\
\hline $\mathrm{E} / \mathrm{e}^{\prime}$ rate & 11.7 (8.3) [4.5-37.5] & 7.1 & $<0.001$ & $9.5(6.4)[4.5-16.2]$ & 13.8 (9.7) [6.1-25.0] & $12.8(10.7)[8-37.5]^{*}$ & 0.005 \\
\hline $\mathrm{e}^{\prime}(\mathrm{cm} / \mathrm{sn})$ & $6.5(1.2)[2.0-14]$ & $9.7(0.6)[6.0-15.0]$ & $<0.001$ & $7.5(2.0)[4.0-14.0]^{\#}$ & $\# \quad 6.0$ (2.0) [2.0-9.0] & $5.5(2.0)[4.0-11.0]$ & $<0.001$ \\
\hline $\mathrm{a}^{\prime}(\mathrm{cm} / \mathrm{sn})$ & $10.4 \pm 2.4$ & $12.1 \pm 2.0$ & 0.001 & $11.2 \pm 0.2$ & $10.3 \pm 0.2$ & $9.7 \pm 0.3$ & 0.078 \\
\hline $\operatorname{IVV}(\mathrm{cm} / \mathrm{sn})$ & $7.0(4.0)$ [4.0-19.0] & $8.7(5.0)[4.0-19.0]$ & $<0.001$ & $7.5(3.0)[4.0-16.0]^{\&}$ & $5.0(2.0)[4.0-9.0]$ & 7.5 (4.0) [2.0-12.0] & 0.016 \\
\hline $\mathrm{Sm}(\mathrm{cm} / \mathrm{sn})$ & $7.0(2.0)$ [3.0-12.0] & $8.2(2.0)[7.0-12.0]$ & $<0.001$ & $8.2(3.0)[5.0-12.0]$ & $6.5(2.0)[3.0-10.0]$ & $6.5(2.0)[3.0-12.0]^{\wedge}$ & 0.029 \\
\hline $\operatorname{IVA}\left(\mathrm{m} / \mathrm{sn}^{2}\right)$ & $2.2(1.4)[0.6-5.7]$ & $2.9(1.9)[1.1-5.5]$ & 0.002 & $2.3(1.1)[1.2-4.2]$ & $1.9(0.7)[1.0-3.7]$ & $2.7(1.7)[0.6-5.7]$ & 0.122 \\
\hline
\end{tabular}




\section{Correlation between TDI Velocities and Conventional Echocardiographic Parameters}

In the Spearman correlation analysis, E/e' ratio, IVS and PW thickness were negatively correlated with AVA, whereas LVMI, e' wave, a' wave and Sm parameters were positively correlated with AVA. When the correlation of echocardiographic parameters with aortic peak gradient (APG) was examined, Sm and e' wave were negatively correlated, whereas E/e', LVMI, IVS, PW thickness were positively correlated. However, there were no correlations between IVA (Table 4).

Table 4. Correlation between tissue Doppler imaging velocities and conventional echocardiographic parameters

\begin{tabular}{lcccc}
\hline & \multicolumn{2}{c}{ Aortic valve area } & \multicolumn{2}{c}{ Aortic peak gradient } \\
\cline { 2 - 5 } & $\mathbf{r}$ & $\mathbf{p}$ & $\mathbf{r}$ & $\mathbf{p}$ \\
\hline E/e' rate & -0.380 & $\mathbf{0 . 0 0 1}$ & 0.363 & $\mathbf{0 . 0 0 1}$ \\
LVMI & 0.413 & $\mathbf{0 . 0 0 1}$ & 0.360 & $\mathbf{0 . 0 0 2}$ \\
Global IVA & 0.039 & 0.744 & 0.090 & 0.444 \\
e' & 0.531 & $<\mathbf{0 . 0 0 1}$ & -0.526 & $<\mathbf{0 . 0 0 1}$ \\
a' & 0.340 & $\mathbf{0 . 0 0 7}$ & -0.201 & 0.087 \\
Sm & 0.388 & $\mathbf{0 . 0 0 1}$ & -0.305 & $\mathbf{0 . 0 0 8}$ \\
IVV & 0.163 & 0.165 & -0.017 & 0.889 \\
IVS & -0.495 & $<\mathbf{0 . 0 0 1}$ & 0.533 & $<\mathbf{0 . 0 0 1}$ \\
PW & -0.487 & $<\mathbf{0 . 0 0 1}$ & 0.518 & $<\mathbf{0 . 0 0 1}$ \\
\hline
\end{tabular}

E: early diastolic flow velocities, e': peak myocardial velocity during early diastole, LVMI: left ventricular mass index, IVA: myocardial acceleration during isovolumic contraction, a': peak myocardial velocity during atrial contraction, Sm: peak myocardial velocity during systole, IVV: peak myocardial velocity during isovolumic contraction, IVS: left ventricular septum thickness, PW: posterior wall thickness

\section{DISCUSSION}

In our study, TDI-derived LV systolic and diastolic velocities were found to be reduced in patients with AS compared to the control group. While we determined the relationship between the severity of stenosis, systolic and diastolic parameters, we were unable to determine the relationship of IVA in the subgroups of AS. This is the first study to compare the severity of AS with LV systolic parameters, with the inclusion of a control group. Thus, we understood that subclinical systolic dysfunction occurred independently of AS severity.

LV systolic function is normal in most patients with severe AS. Impaired myocardial contraction can be detected using the tissue Doppler and/or the speckle tracking strain method without EF decline $(8-16,26)$. Detection of subclinical systolic dysfunction often results in a poor prognosis and has been shown to improve after aortic valve replacement $(15,27,28)$. Similarly, Nieh et al. (29) found that echocardiographic parameters of patients operated for severe AS did not change LV diameter, mass and EF, but improvements in systolic and diastolic parameters measured by TDI were noted at a mean follow-up of 120 days. Subclinical systolic dysfunction detected by TDI has been shown in other valve pathologies and systemic diseases (30-34).

In our study, LVMI, IVS and PW thickness were higher in the AS group compared to the control group, as expected, and this increase correlated with the severity of AS. In the subgroup analysis, likewise Galema et al. (12), LWMI and IVS thickness differed from mild to severe AS, and as with Rajani et al. (35), there was no difference between moderate to severe AS in terms of LWMI. In our study, PW thickness was different between both mild to severe and moderate to severe AS. It is known that LV hypertrophy occurs to compensate for the pressure burden caused by AS (36). Post-operative mortality and morbidity were found to be high in patients with LV hypertrophy and undergoing aortic valve surgery (37). While only $20 \%$ of patients with AS have impaired EF, many patients with preserved EF have experienced increased LVMI heart failure rates and subclinical systolic dysfunction (38).

Although LV EF is not reduced in patients with AS, emerging symptoms such as dyspnea and fatigue have been associated with disturbances in diastolic parameters, measured by non-invasive methods $(8,12,14)$. In our study, diastolic parameters (mitral flow E, A, E/A, DT) measured by conventional methods were different from the control group, regardless of the severity of AS. Galema et al. (12), in their study comparing healthy controls with patients with symptomatic severe AS, as well as Jassal et al. (8) in their own study, divided mild-moderate AS patients into three groups, and similarly to our study, did not find a significant relationship between the degree of stenosis and the traditional diastolic function parameters. When diastolic functions were measured by the more sensitive TDI method, we found that AS was impaired compared to controls and this impairment was associated with the degree of AS, similar to what was reported in other studies $(8,10-13,39)$. Diastolic dysfunction in AS may be associated with increased myocardial stiffness, decreased LV compliance, increased LVMI, increased end-diastolic pressure and impaired LA function. Truong et al. (40) showed that high LV diastolic pressures before transcatheter aortic valve replacement were associated with mortality.

In patients with severe AS, a positive correlation was shown between end-diastolic LV pressure and E/e' ratio, measured by invasive method (10). In addition, E/e' >15 was associated with an elevated mean LA pressure; in our study, the LA diameter, LVMI and E/e' ratio were found to support LV diastolic dysfunction. Polito et al. (41), while comparing moderate and severe AS with the control group, found that the LVMI and E/e' ratio was similarly high. In their study where they used LA volume instead of LA diameter, this value was also significantly higher. In previous studies, increased E/e' was associated with symptoms, surgical necessity and mortality in AS (42).

In many studies, AS patients with preserved systolic function were evaluated for LV subclinical systolic functions by TDI method and a significant decrease was found compared to the control groups $(10,11,13-15,39)$. Systolic dysfunction cannot be detected by conventional echocardiography, but can be detected by the TDI method, LVH and subendocardial ischemia due to increased pressure load, and thus longitudinal contraction is affected (43). The systolic parameters measured by the TDI method are evaluated in the longitudinal axis functions of the left ventricle and show loss of function at the subclinical stage, without obvious LV systolic dysfunction. In our study, Sm, IVV and IVA, which showed LV subclinical systolic dysfunction, were decreased in the AS group, and only the decrease in Sm wave was moderately correlated with AVA and APG. Similar to our study, Poh et al. (39) found 53 patients with AS in their study correlated Sm and AVA index. Barthelemy et al. (34) compared RV function in critically ill patients with invasive 
methods and non-invasive methods, while they could not find the correlation of IVA, but they observed that Sm wave correlated with RV EF.

In our study, although LV IVA decreased in patients with $\mathrm{AS}$, this decrease did not correlate with the severity of stenosis like Sm; this may be due to the Sm wave being affected more by preload and afterload. In support of our study, Ertürk et al. (33) found that LV IVA decreased in patients with mitral stenosis, but could not correlate this decrease with the severity of mitral stenosis. If we consider IVA as the time to overcome the resistance against the stenosis in front of it, in patients with mild AS, the IVA extends for a certain period and remains constant regardless of resistance. This stability suggests that a solid left ventricle is sufficient to overcome the resistance in front of it, regardless of the valve area and gradient. Further clinical studies suggest that IVA may become significant between groups or in the severe AS group, which may be explained by this difference with patients with low EF.

\section{Study Limitations}

Our study had some limitations; the number of patients was low, the systolic function parameters were not compared with parameters measured by invasive methods. In addition, patients were not evaluated with strain/strain rate imaging and the value of systolic function parameters in predicting clinical deterioration and surgery in long-term follow-up was not investigated. Although asymptomatic patients were included in our study, the existing coronary lesions and myocardial ischemia were not known. Patients with systolic dysfunction were not included in our study.

\section{CONCLUSION}

We found that asymptomatic AS with normal EF, systolic and diastolic function parameters measured by the TDI method were impaired and this deterioration was associated with degree of stenosis. We could not determine the relationship with the degree of stenosis by IVA during LV contraction.

Ethics Committee Approval: The study was approved by the Ethics Committee of Istanbul Mehmet Akif Ersoy Thoracic and Cardiovascular Surgery Training and Research Hospital (16.12.2013, 16).

Conflict of Interest: None declared by the authors.

Financial Disclosure: None declared by the authors.

Acknowledgements: None declared by the authors.

\section{REFERENCES}

1. Vahanian A, Baumgartner H, Bax J, Butchart E, Dion R, Filippatos $\mathrm{G}$, et al. Guidelines on the management of valvular heart disease: The Task Force on the Management of Valvular Heart Disease of the European Society of Cardiology. Eur Heart J. 2007;28(2):230-68.

2. Cheitlin MD, Gertz EW, Brundage BH, Carlson CJ, Quash JA, Bode Jr RS. Rate of progression of severity of valvular aortic stenosis in the adult. Am Heart J. 1979;98(6):689-700.

3. Peter M, Hoffmann A, Parker C, Lüscher T, Burckhardt D. Progression of aortic stenosis. Role of age and concomitant coronary artery disease. Chest. 1993;103(6):1715-9.
4. Davies SW, Gershlick AH, Balcon R. Progression of valvar aortic stenosis: a long-term retrospective study. Eur Heart J. 1991;12(1):10-4.

5. Kelly TA, Rothbart RM, Cooper CM, Kaiser DL, Smucker ML, Gibson RS. Comparison of outcome of asymptomatic to symptomatic patients older than 20 years of age with valvular aortic stenosis. Am J Cardiol. 1988;61(1):123-30.

6. Baumgartner H, Falk V, Bax JJ, De Bonis M, Hamm C, Holm PJ, et al. 2017 ESC/EACTS Guidelines for the management of valvular heart disease. Eur Heart J. 2017;38(36):2739-91.

7. Yingchoncharoen T, Gibby C, Rodriguez LL, Grimm RA, Marwick TH. Association of myocardial deformation with outcome in asymptomatic aortic stenosis with normal ejection fraction. Circ Cardiovasc Imaging. 2012;5(6):719-25.

8. Jassal DS, Tam JW, Dumesnil JG, Giannoccaro PJ, Jue J, Pandey AS, et al. Clinical usefulness of tissue Doppler imaging in patients with mild to moderate aortic stenosis: a substudy of the aortic stenosis progression observation measuring effects of rosuvastatin study. J Am Soc Echocardiogr. 2008;21(9):1023-7.

9. Lancellotti P, Donal E, Magne J, O'Connor K, Moonen ML, Cosyns B, et al. Impact of global left ventricular afterload on left ventricular function in asymptomatic severe aortic stenosis: a two-dimensional speckletracking study. Eur J Echocardiogr. 2010;11(6):537-43.

10. Bruch C, Stypmann J, Grude M, Gradaus R, Breithardt G, Wichter T. Tissue Doppler imaging in patients with moderate to severe aortic valve stenosis: clinical usefulness and diagnostic accuracy. Am Heart J. 2004;148(4):696-702.

11. Steine K, Rossebø AB, Stugaard M, Pedersen TR. Left ventricular systolic and diastolic function in asymptomatic patients with moderate aortic stenosis. Am J Cardiol. 2008;102(7):897-901.

12. Galema TW, Yap SC, Geleijnse ML, van Thiel RJ, Lindemans J, ten Cate FJ, et al. Early detection of left ventricular dysfunction by Doppler tissue imaging and N-terminal pro-B-type natriuretic peptide in patients with symptomatic severe aortic stenosis. J Am Soc Echocardiogr. 2008;21(3):257-61.

13. Giorgi D, Di Bello V, Talini E, Palagi C, Delle Donne MG, Nardi C, et al. Myocardial function in severe aortic stenosis before and after aortic valve replacement: a Doppler tissue imaging study. J Am Soc Echocardiogr. 2005;18(1):8-14.

14. Stewart RA, Kerr AJ, Whalley GA, Legget ME, Zeng I, Williams MJ, et al. Left ventricular systolic and diastolic function assessed by tissue Doppler imaging and outcome in asymptomatic aortic stenosis. Eur Heart J. 2010;31(18):2216-22.

15. Lafitte S, Perlant M, Reant P, Serri K, Douard H, DeMaria A, et al. Impact of impaired myocardial deformations on exercise tolerance and prognosis in patients with asymptomatic aortic stenosis. Eur J Echocardiogr. 2009;10(3):414-9.

16. Li CM, Li C, Bai WJ, Zhang XL, Tang H, Qing Z, et al. Value of three-dimensional speckle-tracking in detecting left ventricular dysfunction in patients with aortic valvular diseases. J Am Soc Echocardiogr. 2013;26(11):1245-52. 
17. Miyazaki S, Daimon M, Miyazaki T, Onishi Y, Koiso Y, Nishizaki Y, et al. Global longitudinal strain in relation to the severity of aortic stenosis: a two-dimensional speckletracking study. Echocardiography. 2011;28(7):703-8.

18. Vogel M, Cheung MMH, Li J, Kristiansen SB, Schmidt MR, White PA, et al. Noninvasive assessment of left ventricular force-frequency relationships using tissue Doppler-derived isovolumic acceleration: validation in an animal model. Circulation. 2003;107(12):1647-52.

19. Vogel M, Schmidt MR, Kristiansen SB, Cheung M, White PA, Sorensen K, et al. Validation of myocardial acceleration during isovolumic contraction as a novel noninvasive index of right ventricular contractility: comparison with ventricular pressure-volume relations in an animal model. Circulation. 2002;105(14):1693-9.

20. Dalsgaard M, Snyder EM, Kjaergaard J, Johnson BD, Hassager C, Oh JK. Isovolumic acceleration measured by tissue Doppler echocardiography is preload independent in healthy subjects. Echocardiography. 2007;24(6):572-9.

21. Duan YY, Harada K, Toyono M, Ishii H, Tamura M, Takada G. Effects of acute preload reduction on myocardial velocity during isovolumic contraction and myocardial acceleration in pediatric patients. Pediatr Cardiol. 2006;27(1):32-6.

22. Baumgartner H, Hung J, Bermejo J, Chambers JB, Evangelista A, Griffin BP, et al. Echocardiographic assessment of valve stenosis: EAE/ASE recommendations for clinical practice. J Am Soc Echocardiogr. 2009;22(1):123; quiz 101-2.

23. Devereux RB, Alonso DR, Lutas EM, Gottlieb GJ, Campo E, Sachs I, et al. Echocardiographic assessment of left ventricular hypertrophy: comparison to necropsy findings. Am J Cardiol. 1986;57(6):450-8.

24. Lang RM, Bierig M, Devereux RB, Flachskampf FA, Foster E, Pellikka PA, et al. Recommendations for chamber quantification: a report from the American Society of Echocardiography's Guidelines and Standards Committee and the Chamber Quantification Writing Group, developed in conjunction with the European Association of Echocardiography, a branch of the European Society of Cardiology. J Am Soc Echocardiogr. 2005;18(12):1440-63.

25. Nagueh SF, Appleton CP, Gillebert TC, Marino PN, Oh JK, Smiseth OA, et al. Recommendations for the evaluation of left ventricular diastolic function by echocardiography. $\mathrm{J}$ Am Soc Echocardiogr. 2009;22(2):107-33.

26. Delgado V, Tops LF, van Bommel RJ, van der Kley F, Marsan NA, Klautz RJ, et al. Strain analysis in patients with severe aortic stenosis and preserved left ventricular ejection fraction undergoing surgical valve replacement. Eur Heart J. 2009;30(24):3037-47.

27. Eidet J, Dahle G, Bugge JF, Bendz B, Rein KA, Fosse E, et al. Transcatheter aortic valve implantation and intraoperative left ventricular function: a myocardial tissue Doppler imaging study. J Cardiothorac Vasc Anesth. 2015;29(1):115-20.

28. Poulsen SH, Søgaard P, Nielsen-Kudsk JE, Egeblad H. Recovery of left ventricular systolic longitudinal strain after valve replacement in aortic stenosis and relation to natriuretic peptides. J Am Soc Echocardiogr. 2007;20(7):877-84.

29. Nieh CC, Teo AYH, Soo WM, Lee GK, Singh D, Poh KK. Improvement in left ventricular function assessed by tissue Doppler imaging after aortic valve replacement for severe aortic stenosis. Singapore Med J. 2015;56(12):672-6.

30. Kim YH, Kim JH, Park C. Evaluation of tissue Doppler ultrasonographic and strain imaging for assessment of myocardial dysfunction in dogs with type 1 diabetes mellitus. Am J Vet Res. 2018;79(10):1035-43.

31. Nahar S, Ahmed CM, Shakil SS. Echocardiographic evaluation of right ventricular function in patients with type 2 diabetes mellitus. Mymensingh Med J. 2019;28(2):370-7.

32. Ghandi Y, Sharifi M, Habibi D, Dorreh F, Hashemi M. Evaluation of left ventricular function in obese children without hypertension by a tissue Doppler imaging study. Ann Pediatr Cardiol. 2018;11(1):28-33.

33. Erturk M, Aksu HU, Celik O, Uzun F, Akgul O, Pusuroglu $\mathrm{H}$, et al. Evaluation of the effect of mitral stenosis severity on the left ventricular systolic function using isovolumic myocardial acceleration. Cardiol J. 2014;21(4):442-8.

34. Barthélémy R, Roy X, Javanainen T, Mebazaa A, Chousterman BG. Comparison of echocardiographic indices of right ventricular systolic function and ejection fraction obtained with continuous thermodilution in critically ill patients. Crit Care. 2019;23(1):312.

35. Rajani R, Rimington H, Chambers JB. Treadmill exercise in apparently asymptomatic patients with moderate or severe aortic stenosis: relationship between cardiac index and revealed symptoms. Heart. 2010;96(9):689-95.

36. Jurcut R, Giusca S, La Gerche A, Vasile S, Ginghina C, Voigt JU. The echocardiographic assessment of the right ventricle: what to do in 2010? Eur J Echocardiogr. 2010;11(2):81-96.

37. Orsinelli DA, Aurigemma GP, Battista S, Krendel S, Gaasch WH. Left ventricular hypertrophy and mortality after aortic valve replacement for aortic stenosis. A high risk subgroup identified by preoperative relative wall thickness. J Am Coll Cardiol. 1993;22(6):1679-83.

38. Bauer F, Mghaieth F, Dervaux N, Donal E, Derumeaux G, Cribier A, et al. Preoperative tissue Doppler imaging differentiates beneficial from detrimental left ventricular hypertrophy in patients with surgical aortic stenosis. A postoperative morbidity study. Heart. 2008;94(11):1440-5.

39. Poh KK, Chan MYY, Yang H, Yong QW, Chan YH, Ling LH. Prognostication of valvular aortic stenosis using tissue Doppler echocardiography: underappreciated importance of late diastolic mitral annular velocity. J Am Soc Echocardiogr. 2008;21(5):475-81.

40. Truong VT, Mazur W, Palmer C, Egnaczyk GF, Kereiakes DJ, Sarembock IJ, et al. Impact of high baseline left ventricular filling pressure on transcatheter aortic valve replacement outcomes in patients with significant mitral annular calcification. J Am Soc Echocardiogr. 2019;32(9):1067-74.e1.

41. Polito MV, Stoebe S, Galasso G, De Rosa R, Citro R, Piscione F, et al. Analysis of regional right ventricular function by tissue Doppler imaging in patients with aortic stenosis. J Cardiovasc Echogr. 2019;29(3):111-8.

42. Gomez Perez M, Ble M, Cladellas M, Molina L, Vila J, MasStachurska A, et al. Combined use of tissue Doppler imaging and natriuretic peptides as prognostic marker in asymptomatic aortic stenosis. Int J Cardiol. 2017;228:890-4.

43. Henein MY, Priestley K, Davarashvili T, Buller N, Gibson DG. Early changes in left ventricular subendocardial function after successful coronary angioplasty. Br Heart J. 1993;69(6):501-6. 